-Communication--

\title{
Thermodynamic Stability of $\mathrm{SrCeO}_{3}$ in Aqueous Solutions at $298 \mathrm{~K}$ and in a High-temperature Reductive Atmosphere
}

\author{
Harumi YOKOKAWA ${ }^{\dagger}$, Natsuko SAKAI, Tatsuya KAWADA and Masayuki DOKIYA
}

Received January 10, 1990 ; Accepted March 5, 1990

Strontium Cerate $\left(\mathrm{SrCeO}_{3}\right)$-based perovskites have been extensively investigated as proton conductors by Iwahara and coworkers1,2); they also investigated on chemical stability in aqueous solutions at room temperature and at various high-temperature atmospheres. The objective of the present communication is to make thermodynamic analyses on its stability by using chemical potential diagrams for the $\mathrm{Sr}-\mathrm{Ce}-\mathrm{O}-\mathrm{H}^{-} \mathrm{e}^{-}$system at $298 \mathrm{~K}$ and for the $\mathrm{Sr}-\mathrm{Ce}-\mathrm{O}$ system at 1273 $\mathrm{K}$; these diagrams are compared with experimental results by Uchida et al.2)

High Temperature thermodynamic properties of $\mathrm{SrCeO}_{3}$ have been determined by Levitskii et a1.3) from emf measurements as follows;

$$
\begin{gathered}
\text { SrO }+\mathrm{CeO}_{2}=\mathrm{SrCeO}_{3}, \\
\begin{aligned}
\Delta_{\mathrm{r}^{\circ}} & =\Delta \mathrm{r}^{\circ}-\mathrm{T} \Delta \mathrm{r}^{\circ} \\
& =(-7200-8.9 \mathrm{~T} / \mathrm{K}) \mathrm{J} / \mathrm{mol} .
\end{aligned}
\end{gathered}
$$

The enthalpy of formation at $298 \mathrm{~K}$ and other functions listed in Table 1 were derived from above equations together with estimated heat capacities. The chemical potential diagram for the Sr-Ce-O system was constructed at $1273 \mathrm{~K}$ using the computer program, CHD.4,5) Figure 1 shows the $\log \mathrm{P}\left(\mathrm{O}_{2}\right)$ vs. $\log$ $\{\mathrm{a}(\mathrm{Ce}) / \mathrm{a}(\mathrm{Sr})\}$ plot, where $\mathrm{P}$ and a are the partial pressure and the activity, respectively; $\mathrm{CeO}_{2-\mathrm{x}}$ was treated as a

\begin{tabular}{llrl}
\hline Materials & Chemistry & Division, & National \\
Chemical Laboratory for & Industry, \\
(Tsukuba & Research Center, & Tsukuba, \\
Ibaraki 305, JAPAN) & &
\end{tabular}

Key words: Strontium Cerate, Stability, Decomposition, Dissolution nonstoichiometric compound 6,7$)$ using the SOLGASMIX program. 8,9) Figure 1 indicates that $\mathrm{SrCeO}_{3}$ may decompose at an extremely reductive atmosphere as follows 10 );

$$
\mathrm{SrCeO}_{3}=\mathrm{SrO}+1 / 2 \mathrm{Ce}_{2} \mathrm{O}_{3}+1 / 4 \mathrm{O}_{2}(\mathrm{~g}) .
$$

The equilibrium oxygen partial pressure over a mixture of $\mathrm{SrCeO}_{3}$, SrO and $\mathrm{Ce}_{2} \mathrm{O}_{3}$ is given as $1.62 \times 10^{-22} \mathrm{~atm}$; this corresponds to $\log \mathrm{P}\left(\mathrm{H}_{2} \mathrm{O}\right) / \mathrm{P}\left(\mathrm{H}_{2}\right)=-3.6$. This confirms that $\mathrm{SrCeO}_{3}$ is in a practical sense stable even in pure hydrogen. Actually, Iwahara et al.11) observed from $\mathrm{X}$-ray diffraction studies that $\mathrm{Yb}$-doped $\mathrm{SrCeO}_{3}\left(\mathrm{SrCe}_{0.95} \mathrm{Yb}_{0.05} \mathrm{O}_{3}-\delta\right)$ was stable in wet hydrogen gas $\left(\mathrm{P}_{2} \mathrm{O}\right)=0.013-0.026$ atm) at $1273 \mathrm{~K}$ whereas in dry hydrogen gas (dew point $<233 \mathrm{~K}$ ), it was partially reduced to form $\mathrm{Ce}_{2} \mathrm{O}_{3}$.

The electrochemical potential diagram for the $\mathrm{Sr}-\mathrm{Ce}-\mathrm{O}-\mathrm{H}-\mathrm{e}^{-}$system was constructed as follows: We have recently constructed the electrochemical potential diagrams for multicomponent systems 12 ) and applied to gain insight of the stability of double oxides in aqueous solutions.13) From these chemical thermodynamic considerations, the following criteria were derived to examine the stability of double oxides in aqueous solutions:

(1) Hydration reaction cannot proceed unless the dissolved species promotes reconstruction of cations which is needed for precipitation of other solid state compounds.

(2) Thus, the equilibrium between the double oxide to be considered and aqueous species becomes quite important 
Table 1. Thermodynamic functions of compounds (s1,c) and aqueous species (ao) at 298 $\mathrm{K}$ in the Sr-Ce-O-H- $\mathrm{e}^{-}$system: Enthalpy of formation, $\Delta_{\mathrm{f}} \mathrm{H}^{\circ}$, Gibbs energy of formation, $\Delta \mathrm{f}^{\circ}$, and standard entropy, $\mathrm{S}^{\circ}$, at $298 \mathrm{~K}$ and coefficients of high temperature heat capacity equation: $C_{p}=a+10^{-3} b(T / K)+10^{5} \mathrm{c}(\mathrm{K} / \mathrm{T})^{2}$.

substance state $\frac{\Delta \mathrm{f}^{\mathrm{H}}}{\mathrm{kJ} / \mathrm{mol}} \frac{\Delta \mathrm{f}}{\mathrm{kJ} / \mathrm{mol}} \frac{\mathrm{S}^{\circ}}{\mathrm{J} / \mathrm{mol} \mathrm{K}} \frac{\mathrm{a}}{\mathrm{J} / \mathrm{mol} \mathrm{K}} \mathrm{c} \quad$ ref.

\begin{tabular}{|c|c|c|c|c|c|c|c|c|}
\hline $\mathrm{Ce}_{0.8} \mathrm{O}_{1.2}$ & $\mathrm{~s} 1 * 1$ & -672.2 & -642.6 & 81.20 & 43.13 & 16.56 & -3.68 & 6,7 \\
\hline $\mathrm{CeO}_{2}$ & $\mathrm{~s} 1$ & -1088.7 & -1024.6 & 62.30 & 64.81 & 17.70 & -7.594 & 6,7 \\
\hline Sro & $\mathrm{c}$ & -592.0 & -561.9 & 54.4 & 49.82 & 6.75 & -5.86 & 9 \\
\hline $\mathrm{SrCeO}_{3}$ & $\mathrm{c}$ & -1687.9 & -1596.6 & 125.6 & 114.63 & 24.45 & -13.45 & 3 \\
\hline $\mathrm{Ce}^{3+}$ & ao & -696.2 & -672 . & -205 & & & & 14 \\
\hline $\mathrm{Sr}^{2+}$ & ao & -545.80 & -559.48 & -32.6 & & & & 14 \\
\hline $\mathrm{SrOH}^{+}$ & ao & & -721.3 & & & & & 14 \\
\hline
\end{tabular}

*1 The interaction parameter of the subregular solution (s1) between $\mathrm{CeO}_{2}$ and $\mathrm{Ce}_{0.8} \mathrm{O}_{2}$ is given as $\omega / \mathrm{kJ} \mathrm{mol}^{-1}=[-70.21+63.765(\mathrm{x} 1-\mathrm{x} 2)]-[-32.05+32.05(\mathrm{xl}-\mathrm{x} 2)](\mathrm{T} / \mathrm{K})$, where $\mathrm{x} 1$ and $\mathrm{x} 2$ are mole fraction of $\mathrm{CeO}_{2}$ and $\mathrm{Ce}_{0.8} \mathrm{O}_{2}$, respectively.

to see whether or not the double oxide can dissolve into solutions.

(3) When double oxides dissolve into aqueous solutions, dissolved metallic ions remain as aqueous species or precipitate as hydrated compounds. In the latter case, the system may move to other equilibria containing the precipitated phase or may not reach equilibrium until the initial double oxide completely disappears; in this sense, the presence of water promotes the reconstructive reaction.

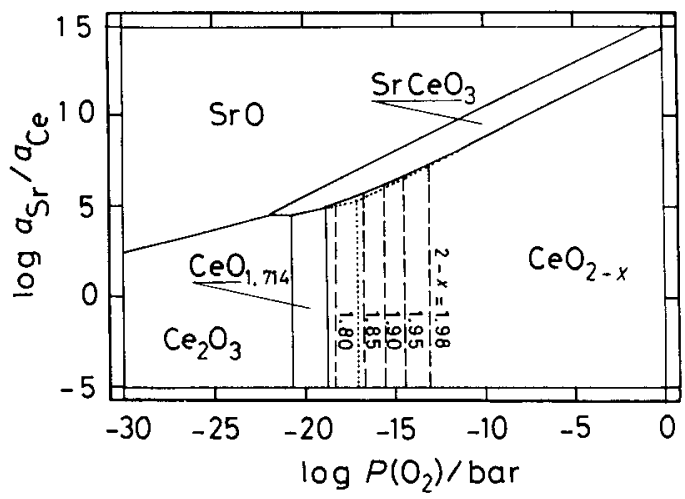

Fig. 1 Chemical potential diagram for Sr-Ce-0 system at 1273 K. Selected oxygen stoichiometric numbers of $\mathrm{CeO}_{2-\mathrm{x}}$ are given.
In the present communication, the stability of $\mathrm{SrCeO}_{3}$ is examined according to the above considerations: First, the hydration reaction of $\mathrm{SrCeO}_{3}$ can be written as

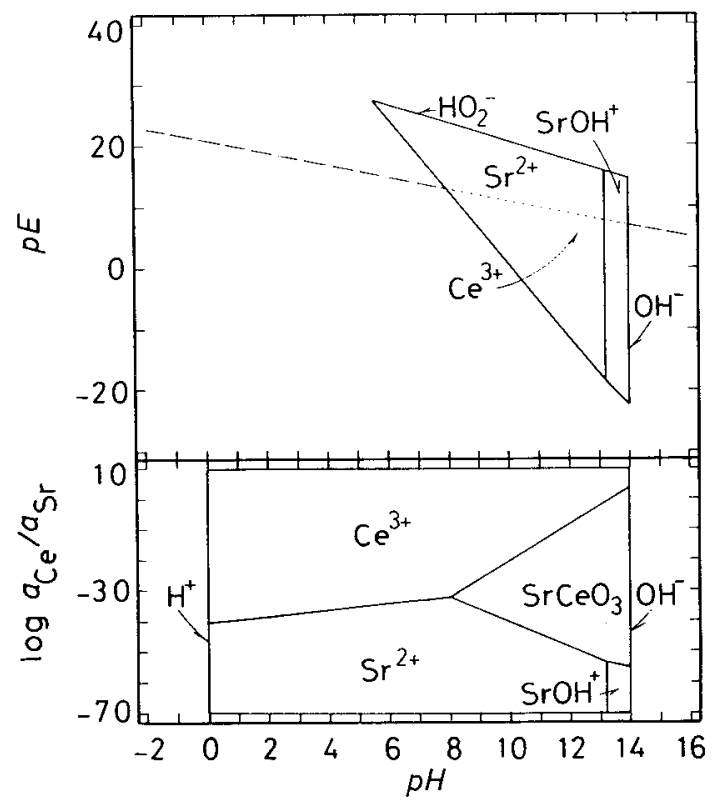

Fig. 2 Electrochemical potential diagram for $\mathrm{Sr}-\mathrm{Ce}-\mathrm{O}-\mathrm{H}-\mathrm{e}^{-} \quad\left(\mathrm{a}\left(\mathrm{H}_{2} \mathrm{O}\right)=1\right)$ system at 298 K. The upper shows the stability region of $\mathrm{SrCeO}_{3}$ presented in a pE vs. pH plot, whereas the lower shows the equilibria between $\mathrm{SrCeO}_{3}$ and aqueous species at $\mathrm{P}\left(\mathrm{O}_{2}\right)=1$ bar. 


$$
\mathrm{SrCeO}_{3}+\mathrm{H}_{2} \mathrm{O}=\mathrm{Sr}(\mathrm{OH})_{2}+\mathrm{CeO}_{2} .
$$

The Gibbs energy change for this reaction can be calculated as $-63.1 \mathrm{~kJ} / \mathrm{mol}$, indicating that $\mathrm{SrCeO}_{3}$ is metastable in the presence of water. As a next step, the electrochemical potential diagram has been constructed to examine the solid-liquid equilibria between $\mathrm{SrCeO}_{3}$ and aqueous species. Fig. 2 shows that $\mathrm{SrCeO}_{3}$ is in equilibrium with $\mathrm{Sr}^{2+}$ and $\mathrm{Ce}^{3+}$ at $\mathrm{P}\left(\mathrm{O}_{2}\right)=1$ bar, and this combination corresponds to the following dissolving reaction;

$$
\begin{aligned}
& \mathrm{SrCeO}_{3}+3 \mathrm{H}_{2} \mathrm{O}+\mathrm{e}^{-} \\
& =\mathrm{Sr}^{2+}+\mathrm{Ce}^{3+}+6 \mathrm{OH}^{-} .
\end{aligned}
$$

Uchida et al.2) experimentally found that $\mathrm{SrCeO}_{3}$ dissolved into hydrochloric acid to evolve $\mathrm{Cl}_{2}(\mathrm{~g})$. This reaction can be written as

$$
\begin{aligned}
& \mathrm{SrCeO}_{3}+3 \mathrm{H}_{2} \mathrm{O}+\mathrm{Cl}^{-} \\
& \quad=\mathrm{Sr}^{2+}+\mathrm{Ce}^{3+}+6 \mathrm{OH}^{-}+1 / 2 \mathrm{Cl}_{2}(\mathrm{~g})
\end{aligned}
$$

This is completely consistent with the present calculational results given by eq. (5). Uchida et al. also found that $\mathrm{SrCeO}_{3}$ slightly dissolved in water, and as a result, the solution became slightly alkaline. In the vicinity of $\mathrm{pH}=7, \mathrm{Ce}^{3+}$ tends to precipitate as follows;

$$
\mathrm{Ce}^{3+}+4 \mathrm{OH}^{-}=\mathrm{CeO}_{2}+2 \mathrm{H}_{2} \mathrm{O}+\mathrm{e}^{-} \text {. }
$$

Since strontium remains as the aqueous species, the overall reaction after combining eqs. (5) and (7) is given as

$$
\mathrm{SrCeO}_{3}+\mathrm{H}_{2} \mathrm{O}=\mathrm{Sr}^{2+}+\mathrm{CeO}_{2}+\mathrm{OH}^{-} \text {. }
$$

This confirms that a slight dissolution of $\mathrm{SrCeO}_{3}$ into water should be accompanied with the increase of $\mathrm{pH}$; note that with increasing $\mathrm{pH}, \mathrm{SrCeO}_{3}$ becomes stable against dissolution and finally approaches the equilibrium state with aqueous species.
We want to acknowledge comments on the manuscript by Professor H. Iwahara, Nagoya University.

\section{REFERENCES}

1) H. Iwahara, T. Esaka, H. Uchida and N. Maeda, Solid state Ionics, 3/4, 359 (1981).

2) H. Uchida, A. Yasuda and H. Iwahara, Denki Kagaku, 57, 153 (1989) and references therein.

3) S. L. Sorokina, Yu. Ya. Skolis, M. L. Kovba and V. A. Levitski, Russ. J. Phys. Chem., 60, 186 (1986).

4) H. Yokokawa, T. Kawada and M. Dokiya, Denki Kagaku, 56, 751 (1988).

5) H. Yokokawa, T. Kawada and M. Dokiya, J. Am. Ceram. Soc., 72, 2104 (1989).

6) T. B. Lindemer, CALPHAD, 10, 129 (1986).

7) H. Yokokawa, N. Sakai, T. Kawada and M. Dokiya, to be published in J. Am. Ceram. Soc.

8) G. Eriksson, Chemica Scripta, 8, 100 (1975).

9) H. Yokokawa, M. Fujishige, S. Ujiie and M. Dokiya, J. Natl. Chem. Lab. Indust., 83 Special issue, 1 (1988).

10) $\mathrm{Sr}_{2} \mathrm{CeO}_{4}$ and other phases are neglected in the present considerations.

11) H. Iwahara, private communication, January (1990).

12) H. Yokokawa, N. Sakai, T. Kawada and M. Dokiya, J. Electrochem. Soc., 137, 388 (1990)

13) H. Yokokawa, N. Sakai, T. Kawada and M. Dokiya, to be published in Denki Kagaku.

14) D. D. Wagman, W. H. Evans, V. B. Parker, R. H. Schumm, I. Halow, S. M. Bailey, K. L. Churney and R. L. Nuttall, J. Phys. Chem. Ref. Data, 11, Supplement No. 2, (1982). 